\title{
Program Kemitraan Masyarakat Pengembangan Usaha Kerajinan Janur di Kabupaten Badung
}

\author{
Riski Martini ${ }^{1 *}$, Intan Priliandani² ${ }^{2}$, Anggita Wahyudi ${ }^{3}$
}

1,2,3 Universitas Warmadewa

\section{A R T I C L E I N F O}

Received 20 August 2019

Received in revised form

10 September 2019

Accepted 30 October 2019

Available online 30

November 2019

Kata Kunci:

Pengrajin Janur

Keywords:

Janur Craftsmen
Article history:

A B S T R A K

Setiap hari raya biasanya masyarakat Hindu di Bali menancapkan penjor yang berbahan dasar dari janur. Karena hal inilah usaha janur perlu dikembangkan lebih luas, selain digunakan pada saat hari raya rangkaian janur juga bisa digunakan saat event wedding sebagai hiasan.Mitra yang digunakan pada program ini adalah Mitra 1 yaitu Ibu Ni Ketut Ayu Wardani dan Mitra 2 yaitu Mangku Riana. Permasalahan yang dihadapi oleh kedua mitra ini adalah Belum memiliki pembukuan atau catatan terkait pendapatan, pengeluaran, biaya produksi dan laba ruginya, belum memahami tata kelola perusahaan terutama dalam hal menentukan strategi produksi dan pemasaran, belum memiliki sistem pemasaran seperti website ataupun sosial media, model dari hiasan janur yang dihasilkan kurang bervariasi. solusi penyelesaian masalah yang ditawarkan adalah Melakukan pendampingan dan membantu dalam pembuatan pembukuan dan laporan keuangan sederhana serta memberikan pelatihan mengenai tata cara pembuatan pembukuan dan pelaporan keuangan sederhana. Pendampingan dan pelatihan ini diharapkan dapat memberikan manfaat ekonomi di masa depan bagi pengembangan usaha pembuatan hiasan janur lbu Ni Ketut Ayu Wartini, memberikan pelatihan mengenai penerapan tata kelola perusahaan terutama berkaitan dengan penentuan strategi produksi maupun pemasaran, membuatkan website untuk membantu dalam pemasaran produk serta melakukan pendampingan dalam penggunaannya, melakukan pendampingan dan mebantu dalam pengembangan desain produk yang dihasilkan sehingga mampu menghasilkan produk yang dapat digunakan untuk event wedding.

\section{A B S T R A C T}

Every holiday, usually the Hindu community in Bali implements penjor which is made from coconut milk. Because of this, the coconut milk business needs to be developed more broadly, besides being used during the holiday, the coconut milk can also be used as a wedding event as decoration. The partners used in this program are Partner 1, Ms. Ni Ketut Ayu Wardani and Partner 2, Mangku Riana. The problems faced by these two partners are: Do not have books or records related to income, expenses, production costs and profit and loss, do not understand corporate governance, especially in terms of determining production and marketing strategies, do not have marketing systems such as websites or social media, models of the resulting decoration less varied. The solution to the problem offered is to provide assistance and assist in the preparation of simple financial books and financial statements and to provide training on the procedures for making simple financial books and reports. This assistance and training is expected to provide future economic benefits for the development of the janitorial business making business Ms. Ni Ketut Ayu Wartini, provides training on the application of corporate governance, especially related to determining production and marketing strategies, making websites to assist in product marketing and mentoring in its use, provide assistance and assist in the development of product designs that are produced so as to produce products that can be used for wedding events.

\footnotetext{
Corresponding author.

E-mail addresses: riskimartini@gmail.com (Riski Martini)
} 


\section{Pendahuluan}

Kreativitas merupakan kemampuan seseorang berfikir dan bertingkah laku. Seseorang yang memiliki kreativitas atau kemampuan berfikir divergensi yang tinggi tidak banyak kesulitan dalam memecahkan masalah yang dihadapinya. Oleh karena itu, kreativitas yang didefinisikan para ahli selalu berkaitan dengan kemampuan berfikir dan bertingkah laku,

Salah satu manfaat kreativitas adalah menghilangkan apa yang tidak disukai semua orang, yaitu masalah. Semua orang punya masalah dan ingin menghilangkannya. Dan salah satu tahapan penting untuk mengatasi masalah adalah menghasilkan ide-ide solusi. Untuk menghasilkan ide, seseorang membutuhkan kreativitas. Semakin kreatif diri kita, maka akan semakin banyak ide yang dihasilkan, akan semakin besar peluang mendapatkan solusi dari masalah yang ada. Banyak orang yang bingung saat ditimpa masalah. Orang kreatif akan menemukan ide untuk dia lakukan. Ide itu tidak pasti berhasil, tetapi setidaknya ada peluang berhasil. Berbeda jika terus dalam kebingungan, tidak akan pernah bisa mengatasi masalahnya (Sari, 2013).

Bali sering digambarkan dengan pulau surga atau pulau dengan seribu pura (A. Fuentes, 2010). Bali memiliki suatu sosok keunikan budaya, yaitu seni dan kerajinan tangannya di praktikan oleh seluruh masyarakatnya (Ruth Daroesman, 2006). Lindsey (2014) menyatakan Bali memiliki daya tarik khusus untuk pariwisata, dimana dengan menyatukan fenomena modern dan memusatkan perhatian pada budaya tradisional sehingga menjadikan budaya Bali tetap terjaga di tengah meningkatnya arus wisata

Upacara dalam agama hindu di Bali masih termasuk upacara yang mengusung kebudayaan tradisional (Swarsi, 2011). Pelaksanaan ritual upacara agama hindu memiliki tujuan untuk menyampaikan perasaan batin umat Hindu kehadapan Tuhan Yang Maha Esa (Ida Sang Hyang Widhi Wasa) atau kehadapan para Leluhur, para Rsi dan kepada para Dewa untuk menuntun pola tingkah laku masyarakat menjadi masyarakat yang berbudi luhur (S. William, 2014). Pelaksanaan upacara agama hindu juga dapat dikatakan sebagai wujud dari aktivitas keagamaan, yaitu berupa kegiatan manusia (Masyarakat Hindu Bali) dalam menyatakan perasaan batin serta mendekatkan dirinya kepada Tuhan (Ida Sang Hyang Widhi Wasa), sebagai bentuk memohon tuntunan, memohon maaf, menyatakan rasa bersyukur, dan memohon keselamatan. Penyelenggaraan upacara dalam Agama Hindu disertai dengan upakara atau banten (Mahardani, 2018).

Penduduk mayoritas di Bali menganut agama Hindu, dimana kepercayaan agama Hindu di Bali sangat kental dengan budaya, tradisi dan adat istiadatnya. Kepercayaan masyarakat Hindu Bali dalam merayakan setiap hari raya dilakukan dengan membuat persembahan sesuai dengan makna dari hari raya tersebut. Salah satunya Hari Raya Galungan makna dari hari raya ini adalah kemenangan "Dharma melawan Adharma", simbol dari makna Hari Raya Galungan ini adalah dengan menancapkan penjor di lebuh (didepan pintu masuk rumah) sebagai wujud serta umat Hindu dalam menegakkan kebenaran sejati, dimana kebenaran yang unggul (Subagiasta, 2010).

Ada 2 jenis penjor yang sering digunakan masyarakat di Bali, yaitu penjor sakral dan penjor profan (Atmaja dkk, 2008). Penjor profan atau yang dikenal dengan pepenjoran merupakan jenis penjor yang digunakan sebagai penghias di hotel, Pesta Kesenian Bali, dan beberapa event diluar upacara keagamaan.Sedangkan penjor sakral adalah penjor yang digunakan pada upacara agama umat Hindu, salah satunya penjor Galungan. Bahan-bahan untuk membuat penjor secara filosofi berasal dari hasil pertanian, seperti plawa (daun-daunan), palawija (biji-bijian seperti padai atau jagung), pala bungkah (umbi-umbian), pala gantung (kelapa dan pisang), satu batang bambu dan hiasan dari busung (daun kelapa muda). Bahan-bahan pembuat penjor ini merupakan bahan lokal yang dapat diperoleh masyarakat dengan mudah, namun seringkali bahan utama penjor seperti busung Bali pada saat mendekati hari raya keagamaan sulit dicari sehingga seringkali penjual busung mendatangkan busung dari daerah luar Bali seperti dari Sulawesi. Selain kelangkaan busung pada saat hari raya keagamaan, penggunaan busung baik busung Bali maupun busung Sulawesi pada penjor sangat tidak awet atau cepat layu, apalagi peruntukan penjor yang ditancapkan di lebuh rumah umat Hindu yang merayakan Galungan selama 1 bulan penuh menyebabkan penjor terpapar sinar matahari sehingga hiasan busung pada penjor menjadi layu. Faktor- faktor ini yang menjadikan beberapa alasan dari peralihan hiasan busung menjadi hiasan janur dari ental. Peralihan hiasan pada penjor dari busung menjadi daun ental dikarenakan daun ental memiliki daya tahan yang lebih lama daripada hiasan dari busung, selain itu hiasan janur dari ental ini juga memiliki bentuk yang beraneka ragam serta memiliki seni yang menarik karena berisi dengan bunga- bunga dan bentuk-bentuk naga ataupun burung, yang menyebabkan bentuknya menjadi semarak.

Ibu Ni Ketut Ayu Wartini dan Mangku Riana merupakan masyarakat yang menekuni usaha pembuatan hiasan janur dari ental. Biasanya ibu Ketut selalu memulai proses produksi hiasan janur tiga bulan sebelum hari Raya Galungan, dimana Ibu Ketut Ayu Wartini telah memiliki warung langganan di Jalan Raya Kapal Badung sehingga dari pihak warung langganan tersebut telah memesan secara khusus 
hiasan janur yang dibuat oleh ibu Ketut Ayu Wartini, harga kisaran ibu Ketut Ayu Wartini menjual hasil hiasan janurnya kepada pemilik warung langganannya adalah sekitar Rp 350.000,- dengan modal untuk pembelian bahan baku sekitar Rp135.000,-, bahan baku tersebut terdiri dari ental, gabus, bunga ratna dari wol, bunga jepun kertas, steples, pita jepang, pita tepi, lem dan biaya kirim. Dimana estimasi biaya pembuatan sebuah hiasan janur yang dibuat Ibu Ketut Ayu Wartini dapat dilihat pada tabel 1.1 berikut:

Tabel 1. Estimasi Biaya Satu Buah Hiasan Janur Produksi Ibu Ketut Ayu Wartini

\begin{tabular}{|c|c|c|c|}
\hline No & Bahan & Kuantitas & Harga \\
\hline 1 & Ental & 2 ikat & Rp 40.000/ikat \\
\hline 2 & Gabus & 1 meter & Rp 15.000,-/meter \\
\hline 3 & $\begin{array}{l}\text { Bunga Jepun } \\
\text { kertas }\end{array}$ & 5 pcs & Rp 25.000/bungkus (isi 100 pcs) \\
\hline 4 & Bunga Ratna & 36 pcs & Rp 7.500/bungkus (isi 100 pcs) \\
\hline 5 & Lem & $\begin{array}{l}\text { Sesuai } \\
\text { kebutuhan }\end{array}$ & Rp 15.000/bungkus \\
\hline 6 & Steples & $\begin{array}{l}\text { Sesuai } \\
\text { kebutuhan }\end{array}$ & Rp 10.000/bungkus \\
\hline 7 & Pita jepang & 1 meter & Rp 5.000/meter \\
\hline 8 & Pita Tepi & 1 meter & Rp 10.000/meter \\
\hline 9 & Biaya Kirim & & Rp 15.000/kirim \\
\hline \multicolumn{3}{|c|}{ Total Biaya Estimasi } & Rp 135.000 \\
\hline
\end{tabular}

Rata-rata penjualan yang diperoleh oleh Ibu Sumerti adalah sebesar Rp 800.000 -1.000.000 per harinya. Pengerajin hiasan janur lainnya yaitu Mangku Riana juga merupakan pengerajin rumahan, bedanya selain menitipkan produknya di warung penjual hiasan janur di Kapal Bapak Putu juga memiliki toko sendiri tempat beliau membuat dan menjajakan produk hiasan janur hasil karyanya. Untuk hiasan janur yang dititipkan di warung di daerah Kapal Bapak Putu mematok harga Rp 250.000,tapi untuk hasil janur yang dijual ditokonya sendiri Pak Putu mematok harga $\mathrm{Rp} 270.000,-$. Untuk modal pembuatan hiasan janur Pak Putu mengeluarkan modal Rp 105.000,- untuk pembelian ental, gabus, bunga ratna dari wol, bunga jepun kertas, steples, pita tepi dan biaya kirim. Adapun estimasi biaya yang dikeluarkan oleh Pak Putu dapat dilihat pada tabel 1.2 sebagai berikut:

Tabel 2. Estimasi Biaya Satu Buah Hiasan Janur Produksi Pak Putu

\begin{tabular}{clcc}
\hline No & \multicolumn{1}{c}{ Bahan } & Kuantitas & Harga \\
\hline 1 & Ental & 2 ikat & Rp 14.000/ikat \\
2 & Gabus & 1 meter & Rp 15.000,-/meter \\
3 & Bunga Jepun kertas & 4 pcs & Rp 27.500/bungkus (isi 100 pcs) \\
4 & Bunga Ratna & 20 pcs & Rp 7.500/bungkus (isi 100 pcs) \\
6 & Steples & Sesuai kebutuhan & Rp 10.000/bungkus \\
8 & Pita Tepi & 1 meter & Rp 8.000/meter \\
9 & Biaya Kirim & & Rp 50.000/kirim \\
& Total Biaya Estimasi & & Rp 105.000 \\
\hline
\end{tabular}

Rata-rata penjualan yang diperoleh oleh Mangku Riana adalah sebesar Rp 800.000 - 1.000.000 per harinya. 

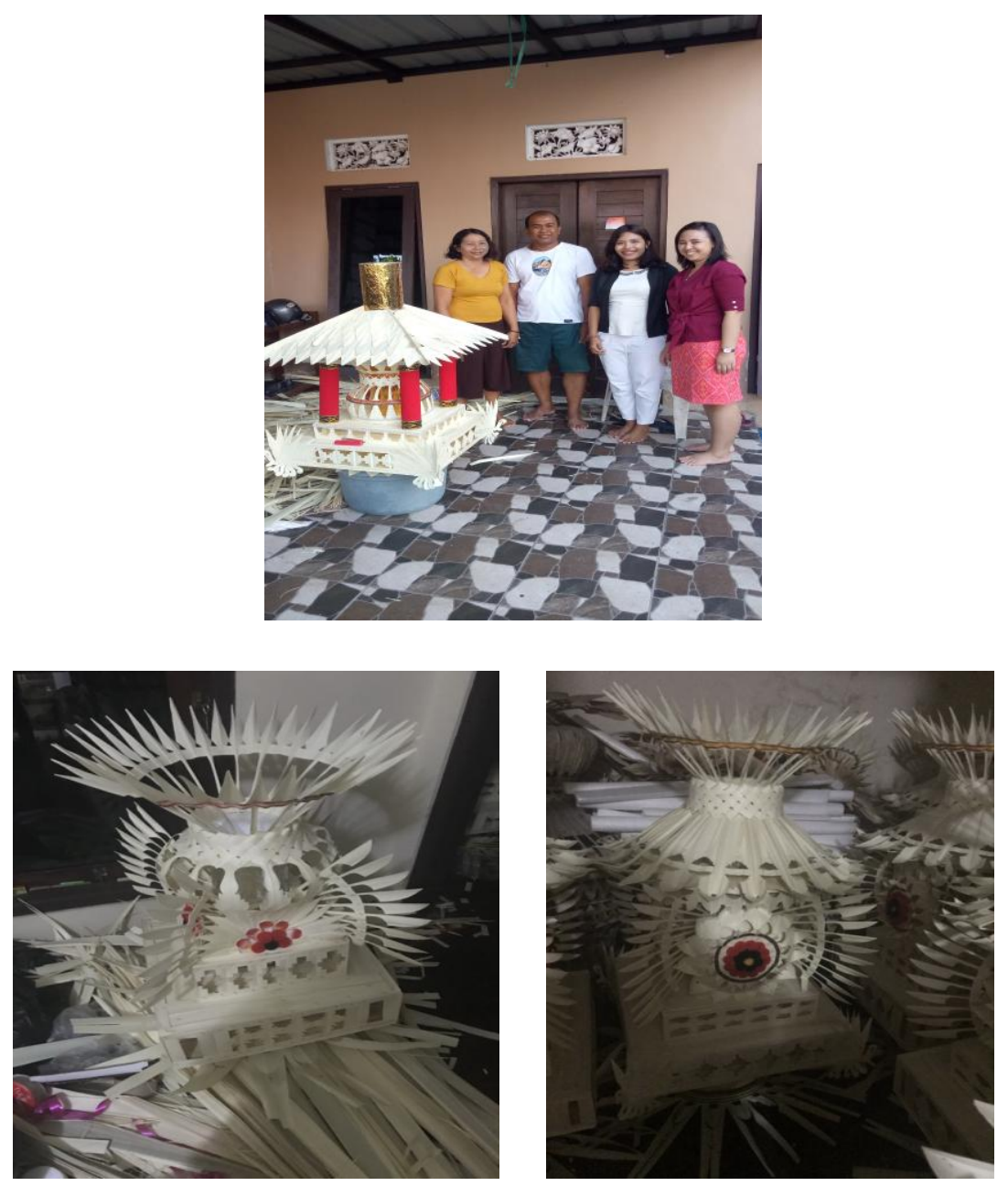

Gambar 1. Profil Ibu Ayu dan Hiasan janur yang diproduksi oleh Ibu Ni Ketut Ayu Wartini
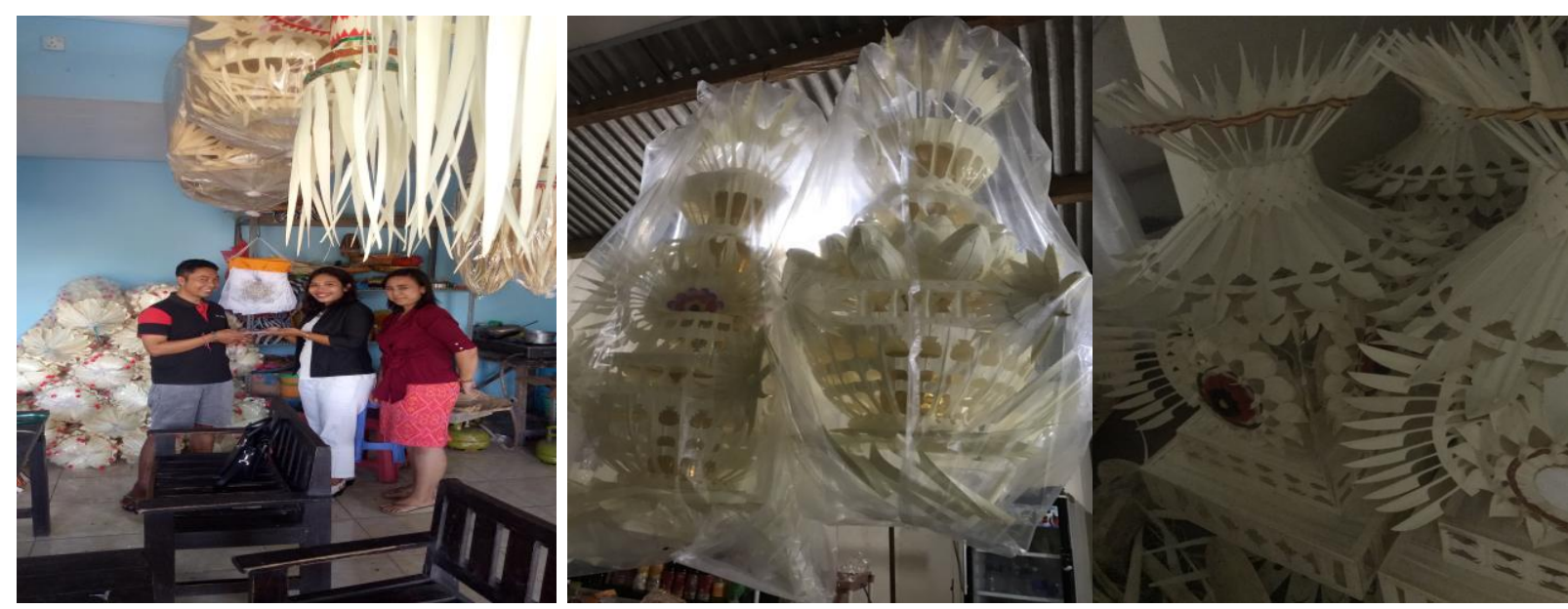

Gambar 2. Profil Bapak Riana Hiasan janur yang dipasarkan oleh Riana

Berkaitan dengan pengelolaan manajemen usaha pembuatan hiasan janur Ibu Ni Ketut Ayu Wartini ini, maka dapat dideskripsikan kondisi dari usaha tersebut adalah sebagai berikut:

1. Manajemen pengelolaan usaha pembuatan janur Ibu Ni Ketut Ayu Wartini belum dilakukan secara professional karena dikelola secara kekeluargaan dan kurang pemahaman terhadap tata kelola perusahaan terutama berkaitan dengan strategi produksi dan pemasaran 
2. Ibu Ni Ketut Ayu Wartini tidak memiliki pembukuan/ catatan harian sama sekali terkait produksi, pendapatan, biaya, laba rugi, sehingga benar-benar tidak mengatahui dengan jelas kondisi dan posisi keuangan usahanya.

3. Usaha pembuatan hiasan janur Ibu Ni Ketut Ayu Wartini belum memiliki model pemasaran untuk mempromosikan hasil usahanya. Selama ini hanya mengandalkan warung langganan sehingga dari pihak warung langganan tersebut telah memesan secara khusus hiasan janur .

4. Desain yang dibuat untuk hiasan janurnya masih bias dikembangkan sehingga hiasan janur yang dihasilkan dapat digunakan untuk dekor acara wedding.

Berdasarkan hasil observasi yang dilakukan pada usaha pembuatan hiasan janur Ibu Ni Ketut Ayu Wartini , terdapat beberapa permasalahan yang menjadi kendala dalam memajukan dan mengembangkan usahanya. Permasalah tersebut adalah sebagai berikut:

1. Belum memiliki pembukuan atau catatan terkait pendapatan, pengeluaran, biaya produksi dan laba ruginya

2. Belum memahami tata kelola perusahaan terutama dalam hal menentukan strategi produksi dan pemasaran.

3. Belum memiliki sistem pemasaran seperti website.

4. Model dari hiasan janur yang dihasilkan kurang bervariasi

Tujuan program pengabdian ini adalah untuk membantu mitra dalam hal ini adalah pengusaha pembuat hiasan janur Ibu $\mathrm{Ni}$ Ketut Ayu Wartini untuk mengatasi permasalah yang dihadapi berkaitan dengan pengembangan usahanya. Dari permasalahan yang dihadapi, maka solusi penyelesaian masalah yang ditawarkan adalah sebagai berikut:

1. Melakukan pendampingan dan membantu dalam pembuatan pembukuan dan laporan keuangan sederhana serta memberikan pelatihan mengenai tata cara pembuatan pembukuan dan pelaporan keuangan sederhana. Pendampingan dan pelatihan ini diharapkan dapat memberikan manfaat ekonomi di masa depan bagi pengembangan usaha pembuatan hiasan janur Ibu Ni Ketut Ayu Wartini

2. Memberikan pelatihan mengenai penerapan tata kelola perusahaan terutama berkaitan dengan penentuan strategi produksi maupun pemasaran.

3. Membuatkan website untuk membantu dalam pemasaran produk serta melakukan pendampingan dalam penggunaannya.

4. Melakukan pendampingan dan mebantu dalam pengembangan desain produk yang dihasilkan sehingga mampu menghasilkan produk yang dapat digunakan untuk event wedding.

\section{Metode}

Adapun solusi yang dapat ditawarkan untuk mengatasi permasalahan mitra tersebut antara lain :

1. Melakukan pendampingan dan membantu dalam pembuatan pembukuan dan laporan keuangan sederhana serta memberikan pelatihan mengenai tata cara pembuatan pembukuan dan pelaporan keuangan sederhana. Pendampingan dan pelatihan ini diharapkan dapat memberikan manfaat ekonomi di masa depan bagi pengembangan usaha pembuatan hiasan janur Ibu Ni Ketut Ayu Wartini. Selain itu diberikan pelatihan mengenai penerapan tata kelola perusahaan terutama berkaitan dengan penentuan strategi produksi maupun pemasaran.

2. Membuatkan website untuk membantu dalam pemasaran produk serta melakukan pendampingan dalam penggunaannya.

3. Melakukan pendampingan dan mebantu dalam pengembangan desain produk yang dihasilkan sehingga mampu menghasilkan produk yang dapat digunakan untuk event wedding.

\section{Hasil dan pembahasan}

Berdasarkan permasalahan yang akan diselesaikan pada masing-masing mitra, maka hal-hal yang akan dilakukan selama kegiatan meliputi:

1. Pendampingan dan membantu dalam pembuatan pembukuan dan laporan keuangan sederhana.

2. Pelatihan penerapan tata kelola perusahaan

3. Pelatihan dalam membuat sistem pemasaran produk

4. Pembuatan desain janur

Berikut ini capaian pelaksanaan kegiatan sesuai dengan yang diprioritaskan pada masing-masing mitra, yaitu: 
1) Pemberian pendampingan dan pelatihan pembukuan sederhana, menjelaskan pencatatan sederhana bagaimana cara mencatat biaya - biaya produksi dan mencatat penjualan. Memisahkan keuangan prbadi dengan keuangan hasil usaha sekaligus pelatihan penerapan tata kelola perusahaan
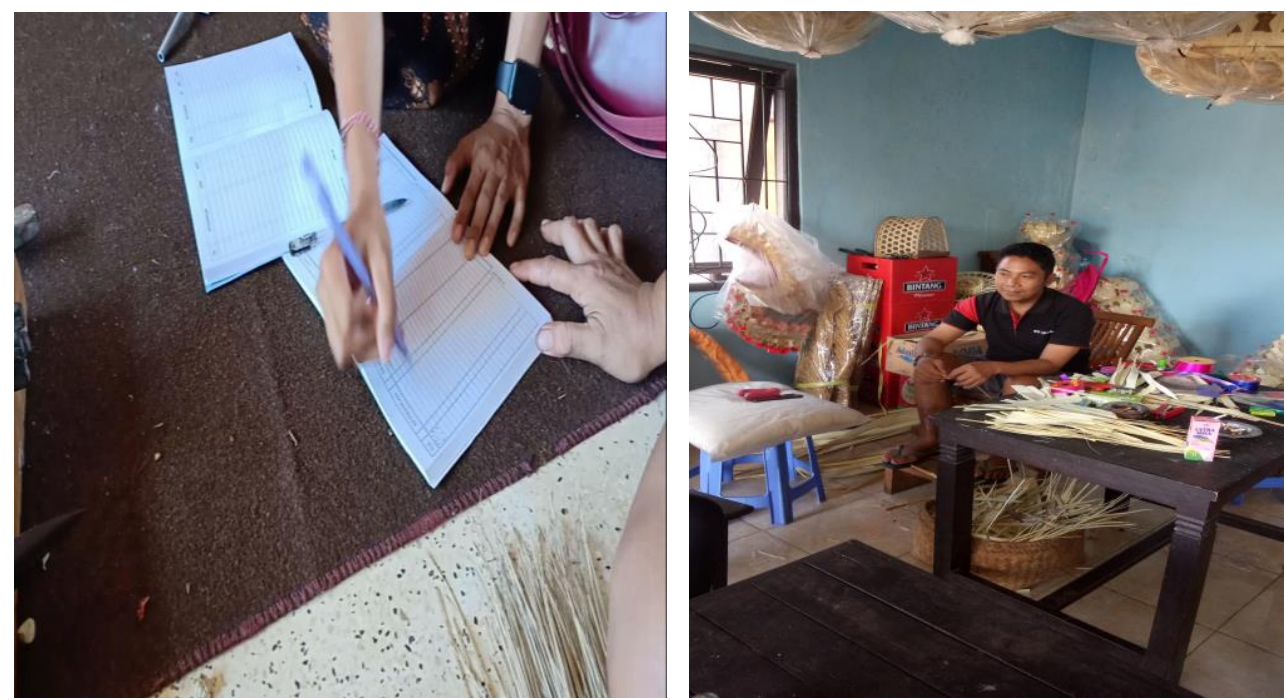

Gambar 3. Pendampingan Pelatihan Pembukuan

2) Pembuatan website masing - masing mitra bertujuan untuk memperluas segmentasi pasar. Website mitra I : geboganmengwi.blogspot.com

Mitra II: janurmengwi.blogspot.com

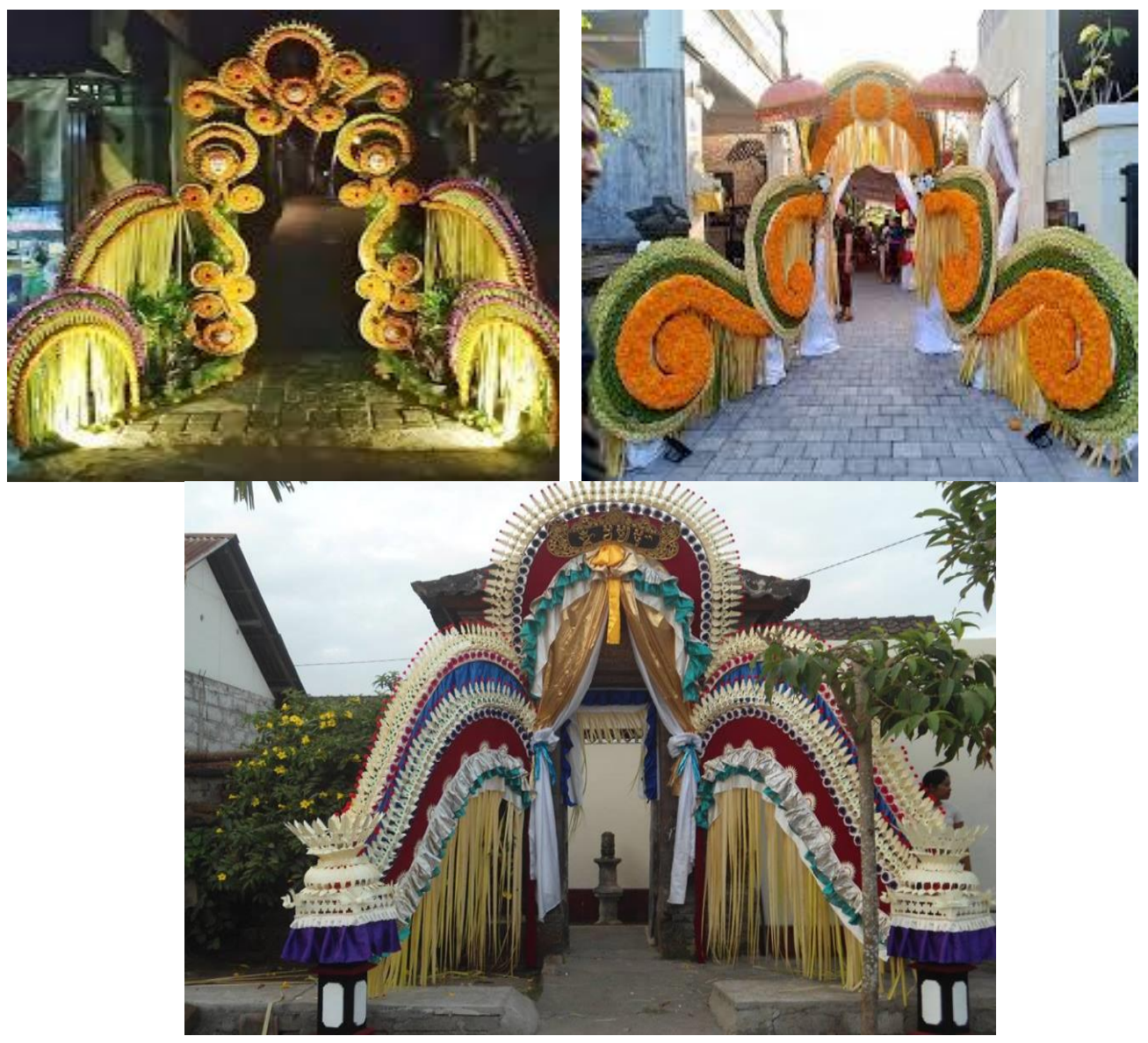

Gambar 4. Pembuatan desain janur 


\section{Simpulan dan saran}

Berdasarkan atas kegiatan yang telah dilaksanakan, dapat disimpulkan bahwa terdapat beberapa permasalahan yang menjadi kendala dalam memajukan dan mengembangkan usahanya. Permasalah tersebut adalah sebagai berikut:

1. Belum memiliki pembukuan atau catatan terkait pendapatan, pengeluaran, biaya produksi dan laba ruginya. Sehingga

2. Belum memahami tata kelola perusahaan terutama dalam hal menentukan strategi produksi dan pemasaran.

3. Belum memiliki sistem pemasaran seperti website.

4. Model dari hiasan janur yang dihasilkan kurang bervariasi

Pelaksanaan pengabdian ini diharapkan dapat menyasar mitra lain dengan usaha sejenis, sehingga melakukan pengembangan potensi usaha yang tinggi, perlu bagi mitra untuk memiliki kompetensi yang memadai. Selain dari bidang keuangan dan pemasaran, para mitra juga peru diberikan penyuluhan dari segi aspek hukum terutama mengenai ijin usaha dan paten produk.

\section{Daftar Rujukan}

Atmaja, I Made Nada, dkk.2008. Nilai Filosofis Penjor Galungan dan Kuningan. Surabaya: Paramita.

Mahardani, Ida Ayu Sri. 2018. Pengaruh Harga dan Pendapatan Konsumen Terhadap Permintaan Janur Di Desa Ubud, Kabupaten Gianyar. E-Jurnal Ekonomi Pembangunan Universitas Udayana Vol. 7 No. 5 Mei 2018

Priwibowo, dkk.2015. Penetapan Harga Jual Tepung Mocaf Dengan Menggunakan MetodeTarget Profit PricingDanCost Reduction.Reka Integra - ISSN : 2338-5081

Sari, Debi Olivia. 2013. Pelatihan Kerajinan Tangan Dari Kain Flanel Sebagai Pemberdayaan . Jurnal Inovasi dan Kewirausahaan. Volume 2 No. 2, Mei 2013

Subagiasta, I Ketut. 2010. Hari Raya Galungan (Kajian Filosofis dan Teologi).

Warta Hindu Dharma N0. 527 Nopember 2010 http://phdi.or.id/artikel/hari-raya-galungan-kajianfilosofis-dan- teologi-3 